\title{
MODELLING OF NEUTRON AND PHOTON TRANSPORT IN IRON AND CONCRETE RADIATION SHIELDINGS BY THE MONTE CARLO METHOD
}

\author{
A. Žukauskaité ${ }^{a}$, R. Plukienè ${ }^{\mathrm{a}}$, A. Plukis ${ }^{\mathrm{a}}$, and D. Ridikas ${ }^{\mathrm{b}}$ \\ a Institute of Physics, Savanoriu 231, LT-02300, Vilnius, Lithuania \\ ${ }^{\mathrm{b}}$ C.E.A. Saclay, DSM/DAPNIA/SPhN, F-91191 Gif-sur-Yvette Cedex, France \\ E-mail: agne.zukauskaite@ff.vu.lt
}

Received 5 December 2006

\begin{abstract}
Particle accelerators and other high energy facilities produce penetrating ionizing radiation (neutrons and $\gamma$-rays) that must be shielded. The objective of this work was to model photon and neutron transport in various materials usually used for shielding, such as concrete, iron, or graphite. The Monte Carlo method allows one to obtain particle flux and nuclear reaction rates by simulating individual particles and recording some aspects of their average behaviour. In this work several nuclear experiments were modelled: AVF 65 - $\gamma$-ray beam (1-10 MeV) transport, HIMAC and ISIS 800 - high energy neutron (20$800 \mathrm{MeV}$ ) transport in iron and concrete. Then the results were compared with experimental data.
\end{abstract}

Keywords: Monte Carlo method, shielding, radioprotection

PACS: 28.20.-v, 02.70.Uu

\section{Introduction}

Nuclear reactors, particle accelerators, and other nuclear facilities produce penetrating ionizing radiation (neutrons and high energy photons) that could be harmful to personnel. To protect people from this radiation, protective shields that attenuate fluxes of energetic particles must be foreseen and installed $[1,2]$.

On some occasions it is difficult to determine what kind and amount of protection will be needed, and it would be very convenient to use computer simulations to solve this problem. MCNP-4A, MORSE [3], ANISN [4], and other codes were used to model conducted experiments to see whether the results of such simulations are reliable.

The objective of this work was to model photon and neutron transport in various materials, usually used as shielding, such as concrete, iron or graphite. Modelling of neutron and photon transport in iron and concrete radiation shieldings was performed by using the Monte Carlo method. The Monte Carlo method can be used to duplicate a statistical process (such as the interaction of nuclear particles with materials) theoretically and is particularly useful for complex problems that cannot be modelled by computer codes that use deterministic methods. In this work several high energy particle and photon shielding experiments were modelled: AVF 65 (AVF cyclotron Research Center of Nuclear Physics, Osaka University) [3] - $\gamma$-ray beam $(1-10 \mathrm{MeV})$ transport in iron and concrete, HIMAC (heavy-ion synchrotron of the National Institute of Radiological Sciences in Chiba, Japan) [5] - high energy neutron (20$800 \mathrm{MeV}$ ) transport in iron, and ISIS 800 (ISIS intensive spallation neutron source facility of the Rutherford Appleton laboratory, UK) [4] - deep-penetration of neutrons through concrete and iron shieldings. The obtained results were compared with experimental data.

\section{Methods}

Calculations were done with the MCNPX [6] multiparticle transport code using LA150 [7] and ENDF-VI [8] cross-section libraries and the Bertini intra-nuclear cascade model for high energies. The extended version of the Monte Carlo N-Particle Code MCNPX is applied to the neutron and $\gamma$-particle (photon) transport calculations. The Monte Carlo method allows one to obtain the particle flux and nuclear reaction rates by simulating individual particles and recording some aspects of their average behaviour. The individual probabilistic events are simulated sequentially. The probability distributions governing these events are statistically 

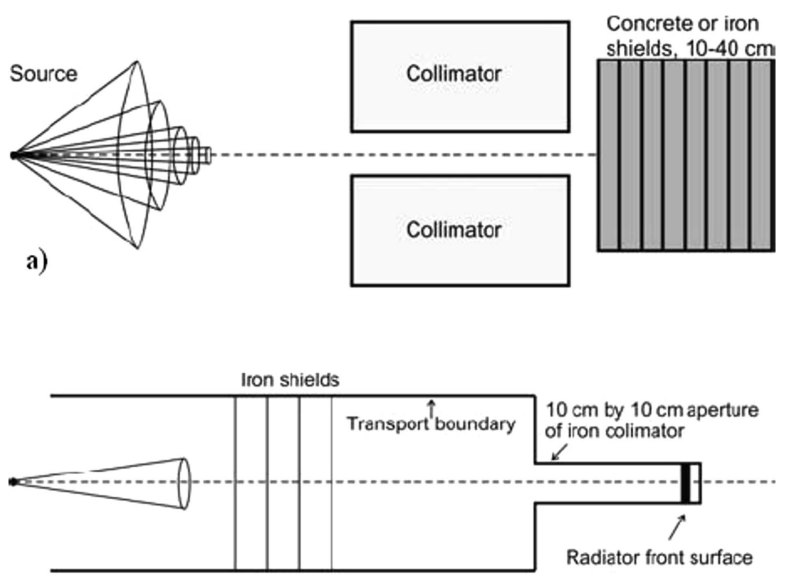

b)

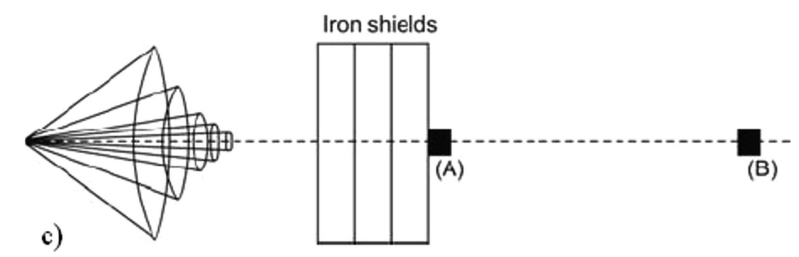

Fig. 1. Geometry used in calculations: (a) AVF 65 (with $50 \mathrm{~cm}$ long and $7.5 \mathrm{~cm}$ diameter concrete collimator); (b) Self-TOF; (c) NE213 ( $A$ and $B$ are positions for calculating the neutron flux).

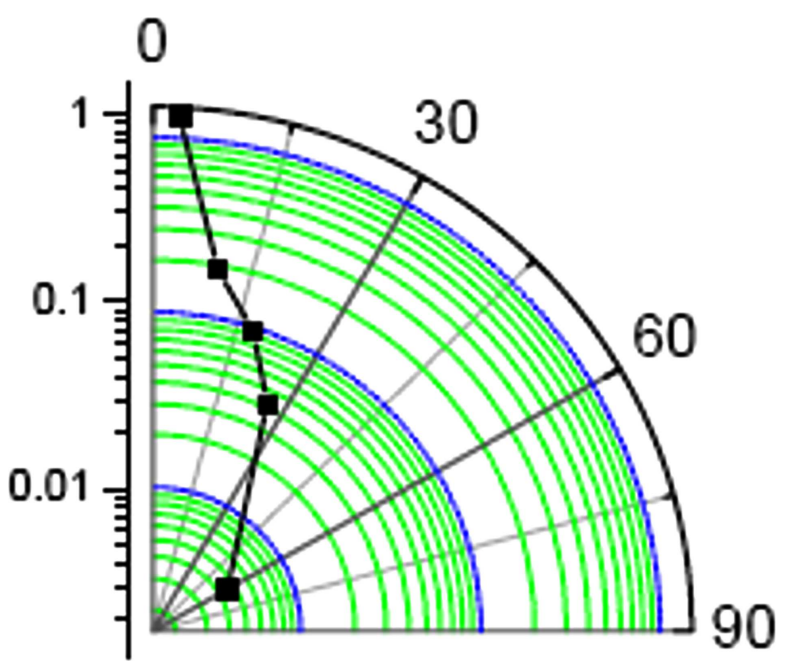

Fig. 2. Angular $\gamma$-ray source distribution in the copper target in the AVF 65 experiment. The direction of 0 degrees is towards the collimator.

sampled to describe the total phenomenon. As input data the MCNPX code requires nuclear data, materials, and a detailed geometry description. For the particle flux spectra, neutron and photon transport has been taken into account. Several different set-ups were modelled for benchmarking AVF 65, HIMAC [3] (Self-TOF and NE213 detectors), and ISIS 800 [4] experiments.

When modelling the photon flux originating from the AVF 65 photon cyclotron the $65 \mathrm{MeV}$ proton beam was modelled $380 \mathrm{~cm}$ away from the shielding plates
(Fig. 1(a)). Protons from the source hit the $1.0 \mathrm{~cm}$ thick (stopping length) copper target. The total neutron and photon flux, energy, and angular distribution were calculated near the copper target and used as a secondary source in calculations afterwards (Fig. 2). Secondary particles then pass through a $7.5 \mathrm{~cm}$ diameter, $50 \mathrm{~cm}$ long iron-lined concrete collimator to the iron or concrete shielding (transverse dimensions $40 \times 40 \mathrm{~cm}^{2}$, and width ranging from 10 to $40 \mathrm{~cm}$ ). For neutron shielding the source neutron spectrum was taken from [5]. The calculation geometry for comparison with the results of Self-TOF and NE213 scintillator detectors is shown in Fig. 1(b,c), the room wall and other equipment in the room were not considered in the simulation. The selfTOF detector was placed $509 \mathrm{~cm}$ from the source. For the NE213 detector, the neutron flux was calculated in position $(A)-233 \mathrm{~cm}$ from the source and position $(B)$ was at $503 \mathrm{~cm}$ (see Fig. 1(c) for details).

The shielding was divided into several regions every $5 \mathrm{~cm}$ in order to observe the attenuation of neutrons and $\gamma$-rays and to determine the importance of particle transport in each region. The photon flux decreases nearly by 6 orders of magnitude in the last region of the shielding in the low energy range, while a somewhat smaller attenuation is observed for high energy photons. For this reason specific variance reduction techniques were needed to increase the statistics of the Monte Carlo calculations. For example, the neutron tracking transport importance in MCNPX was gradually increased from 1 to $10^{5}$ starting from the initial to the last region of the shielding, otherwise it would be impossible to obtain a statistically significant result in a reasonable computing time.

For the photon flux calculations, statistics of up to $10^{9}$ particles was used, while for the neutron flux calculations up to $10^{7}$ particles were simulated.

\section{Results and conclusions}

The photon and neutron fluxes in the concrete and iron shielding were calculated and compared with experiments. Photon spectra in iron and concrete for AVF 65 are shown in Fig. 3 (a,b). In Table 1 the total flux in concrete and iron is compared with the experiment. Here the total flux at 20 or $50 \mathrm{~cm}$ thickness of the shielding was divided by the total flux at $0 \mathrm{~cm}$ of the shielding. From this table as well as from photon spectra (Fig. 3(a,b)) we can see that the agreement between experiment and calculation with MCNPX in concrete is sufficient, but for iron the obtained difference is too large and should be analysed more carefully. The large 


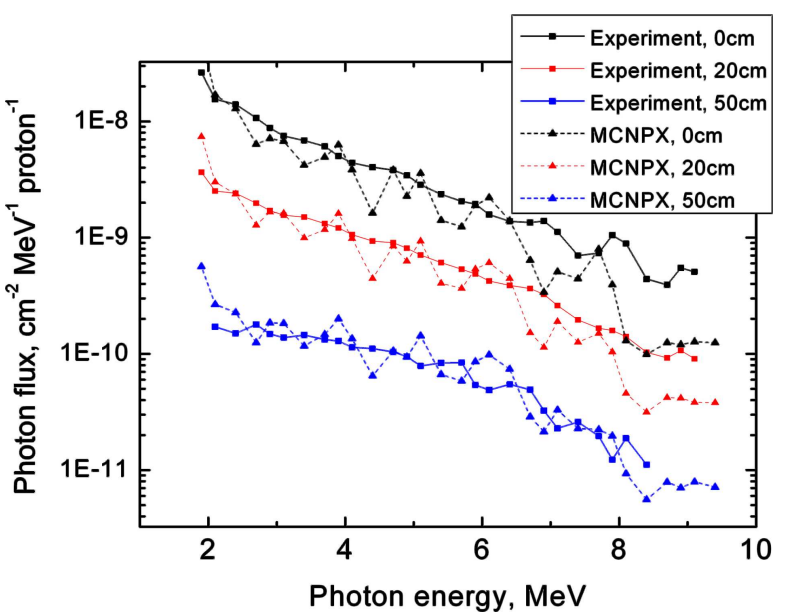

(a)

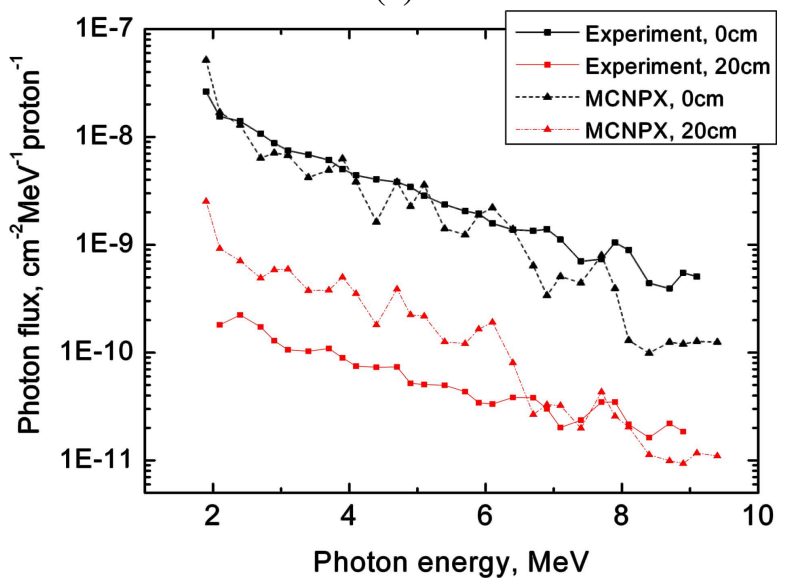

(b)

Fig. 3. Photon spectra calculated with MCNPX and experimentally measured behind (a) concrete shielding (thicknesses 20 and $50 \mathrm{~cm}$ ) in the AVF 65 experiment; (b) the iron shielding (thickness $20 \mathrm{~cm}$ ) in the AVF 65 experiment.

discrepancies in calculation of the photon flux in iron may be associated with different MCNPX modelling of gammas coming from neutron capture compared with real experiment conditions.

The high energy neutron spectra calculated with MCNPX and experimentally measured ones using the Self-TOF detector for different thicknesses of the iron shielding are presented in Fig. 4. The modelling prediction is sufficiently good compared with experimental values.

The high energy neutron fluxes and spectra were also calculated for the $60 \mathrm{~cm}$ thick concrete shielding of ISIS 800 (Fig. 5). The graphite samples were inserted between shielding plates and were used for activation measurements. The ${ }^{12} \mathrm{C}(\mathrm{n}, 2 \mathrm{n}){ }^{11} \mathrm{C}$ reaction rates were calculated with MCNPX using neutron fluxes and spectra modelled previously. The reaction rates in the concrete shielding were compared to experimental results

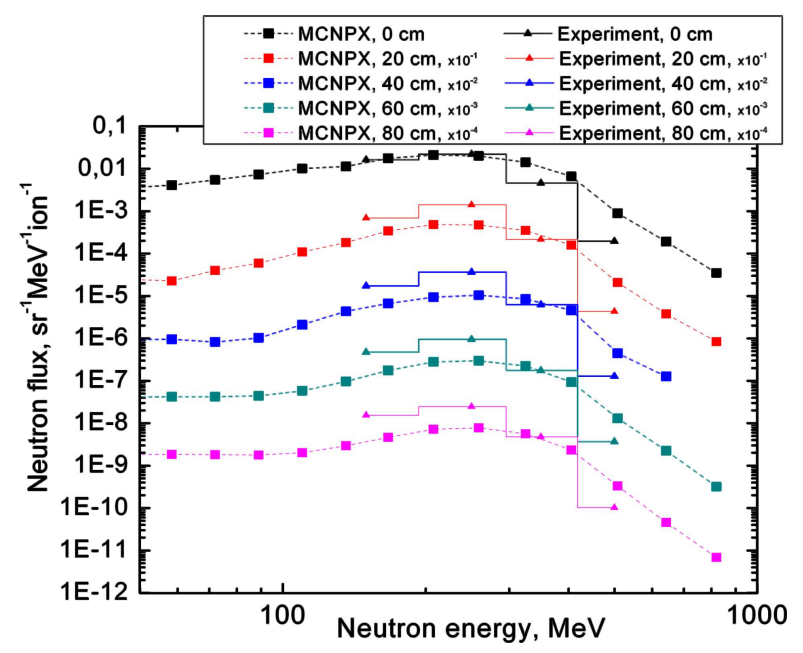

Fig. 4. High energy neutron spectra calculated with MCNPX and experimentally measured using the Self-TOF detector for the different thicknesses of iron shielding.

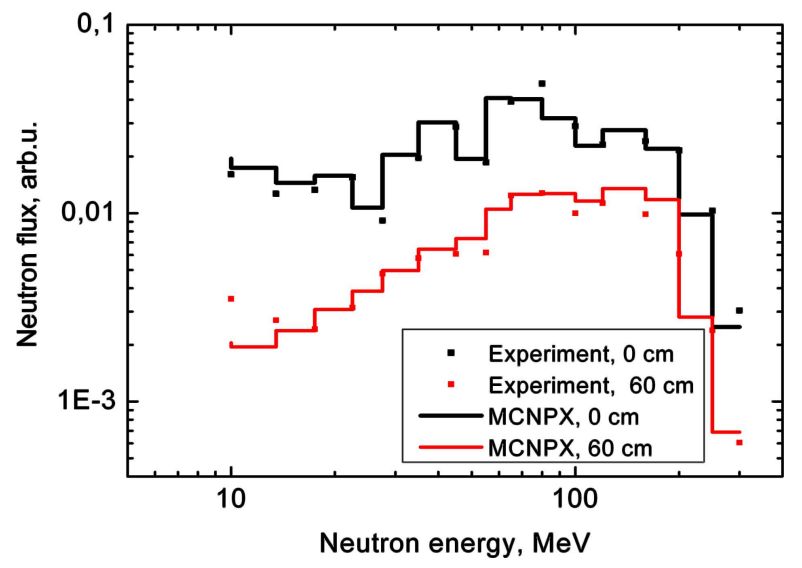

Fig. 5. Neutron energy spectra on the top floor $(0 \mathrm{~cm})$ of the shielding and behind a $60 \mathrm{~cm}$ additional concrete shieldings calculated using MCNPX and experimentally measured in ISIS 800.

as shown in Fig. 6. According to the obtained results we can say that MCNPX modelling can be used for fast neutron flux determination.

The neutron flux results were checked by additional MCNPX calculations using different neutron data libraries: ENDF, JEFF, JENDL, LANL, and intranuclear cascade physics models: Bertini, Isabel, CEM2k, and INCL. The difference was less than 5\%, therefore insignificant compared to modelling and experimental uncertainties.

From the results introduced above it has been concluded that the 1-10 MeV energy photon transport in the concrete shielding can be adequately modelled using MCNPX, but the photon flux in iron is significantly higher than corresponding experimental data. Such photon modelling results observed in iron may be influenced by gammas coming from neutron capture. 
Table 1. Comparison of shielding of photon flux in AVF 65 between experimental and modelling results with MCNPX.

\begin{tabular}{lcccc}
\hline Material & \multicolumn{2}{c}{ Concrete } & & Iron \\
\cline { 2 - 3 } Ratio at different thicknesses of the shielding & $20 \mathrm{~cm} / 0 \mathrm{~cm}$ & $50 \mathrm{~cm} / 0 \mathrm{~cm}$ & & $20 \mathrm{~cm} / 0 \mathrm{~cm}$ \\
\hline Experiment & 0.19 & 0.016 & 0.014 \\
MCNPX & 0.21 & 0.025 & 0.069 \\
\hline
\end{tabular}

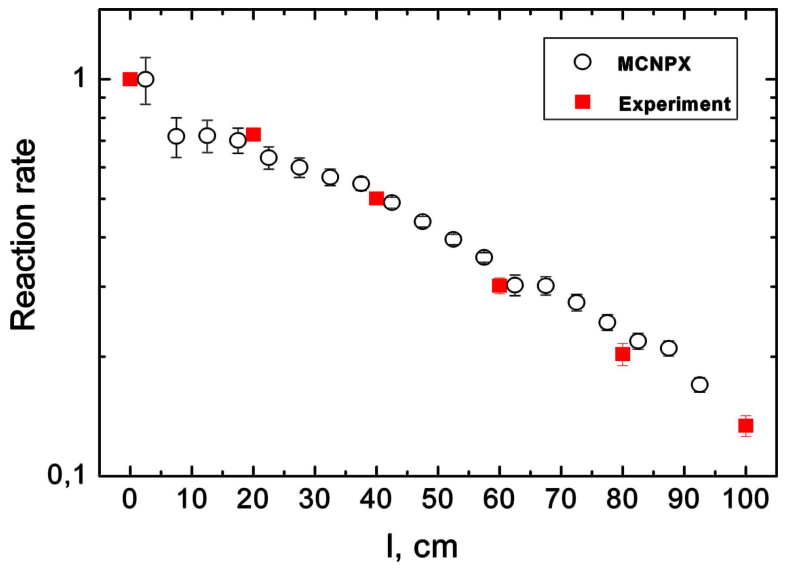

Fig. 6. Distribution of the ${ }^{12} \mathrm{C}(\mathrm{n}, 2 \mathrm{n})^{11} \mathrm{C}$ reaction rates at different depth $(l)$ of the concrete shielding, calculated with MCNPX and experimentally measured in ISIS 800 .

Moreover, the shielding of high energy (20-800 MeV) neutrons in iron is modelled sufficiently well by the Monte Carlo method. Best agreement is obtained for neutrons with energies higher than $100 \mathrm{MeV}$. On the whole, the results obtained show that the MCNPX code can be successfully used for accelerator radioprotection assessment.

\section{Acknowledgement}

We acknowledge the financial support of the EC under the FP6 "Research Infrastructure Action - Structuring the European Research Area" EURISOL DS Project; Contract No. 515768 RIDS; www.eurisol.org . The EC is not liable for any use that may be made of the information contained herein.

\section{References}

[1] A. Plukis, R. Plukienè, V. Remeikis, R. Davidonis, P. Kučinskas, and D. Ridikas, Evaluation of radiation shielding of RBMK-1500 reactor spent nuclear fuel containers using MCNP5, Lithuanian J. Phys. 46(3), 367374 (2006).

[2] J.L. Biarrotte, S. Bousson, T. Junquera, A.C. Mueller, and A. Olivier, A reference accelerator scheme for ADS applications, Nucl. Instrum. Methods A 562(2), 656661 (2006).

[3] H. Nakashima, Y. Sakamoto, S. Tanaka et al, Benchmark Problems for Intermediate and High Energy Accelerator Shielding, JAERI-Data / Code 94-012 (1994).

[4] T. Nunomiya, N. Nakao, P. Wright et al, Experimental Data of Deep-Penetration Neutrons through a Concrete and Iron Shield at the ISIS Spallation Neutron Source Facility using an $800 \mathrm{MeV}$ Proton Beam, KEK Report 2001-24 (2002).

[5] T. Kurosawa, N. Nakao, T. Nakamura, Y. Uwamino, T. Shibata, A. Fukumura, and K. Murakami, Measurements of secondary neutrons produced from thick targets bombarded by high-energy helium and carbon ions, Nucl. Sci. Eng. 132, 30-57 (1999).

[6] MCNPX - Monte Carlo N-Particle Transport Code System for Multiparticle and High Energy Applications, http://mcnpx.lanl.gov/.

[7] M.B. Chadwick, P.G. Young, R.E. MacFarlane, P. Moller, G.M. Hale, R.C. Little, A.J. Koning, and S. Chiba, LA150 Documentation of Cross Sections, Heating, and Damage, Los Alamos National Laboratory Report LA-UR-99-1222 (1999).

[8] J.S. Hendricks, S.C. Frankle, and J.D. Court, ENDF/BVI Data for MCNP, Los Alamos National Laboratory Report LA-12891 (1994). 


\title{
NEUTRONŲ IR $\gamma$ SPINDULIU SKVERBIMOSI PRO GELEŽİ IR BETONĄ MODELIAVIMAS MONTE KARLO METODU
}

\author{
A. Žukauskaite ${ }^{\mathrm{a}}$, R. Plukiené ${ }^{\mathrm{a}}$, A. Plukis ${ }^{\mathrm{a}}$, D. Ridikas ${ }^{\mathrm{b}}$ \\ ${ }^{a}$ Fizikos institutas, Vilnius, Lietuva \\ ${ }^{\text {b } C . E . A . ~ S a c l a y, ~ P r a n c u ̄ z i j a ~}$
}

\section{Santrauka}

Daleliu greitintuvuose ir kituose aukštų energiju įrenginiuose sukuriama personalui pavojinga jonizuojančioji spinduliuotė (neutronai ir $\gamma$ spinduliai). Norint apsaugoti žmones nuo žalingo spinduliuotès poveikio, tokius įrenginius būtina ekranuoti. Modeliuotas neutronų ir fotonų skverbimasis pro i̇vairias ekranavimui naudojamas medžiagas, tokias kaip geležis ar betonas. Naudotas Monte Karlo metodas yra pagrịstas individualių dalelių pernašos modeliavimu, o rezultatai gaunami iš suvidurkintos šių dalelių elg- senos. Pateikiami rezultatai, kurie buvo gauti modeliuojant keletą branduolinių eksperimentu, tokių kaip AVF $65-\gamma$ spindulių (1-10 MeV) skverbimasis; HIMAC ir ISIS 800 - didelių energijų (20-800 MeV) neutronu skverbimasis pro betoną ir geležį. Modeliavimo rezultatai palyginti su literatūroje pateikiamais eksperimentiniais duomenimis. Geriausiai eksperimento duomenis atitiko $100 \mathrm{MeV}$ ir didesnių energijų neutronų srautai geležyje. Rezultatai parodè, kad ši metodą galima sẻkmingai taikyti, sprendžiant radiacinès saugos uždavinius. 